\title{
CORPORATE TAX RATES IN THE SADC REGION: DETERMINANTS AND POLICY IMPLICATIONS
}

\author{
ZURIKA ROBINSON*
}

\begin{abstract}
Since the 1990s the SADC region has closely followed declining trends that occurred in the industrialised world in terms of corporate tax rates. The main purpose of this paper is to find appropriate explanations behind these trends as experienced in the SADC region. A cross-section panel, including the so-called Seemingly Unrelated Regression (SUR), is applied to uncover the main determinants of corporate tax rates in the region.

The main findings of the paper acknowledge the vulnerability of corporate tax rates to global influence. The presence-of-trade variable relating to openness and international pressure takes precedence in the determination of corporate tax rates. The results indicate that higher trade ratios mean lower statutory corporate rates as international influence intensifies. It also tends to confirm the region's dependency on trade for tax revenues, but also its ability to still attract tax revenues from capital flows. Some evidence exists in terms of an association between the government expenditure-GDP ratio and the statutory and average corporate tax rates, although this is not definitive. The paper re-emphasises the importance of international pressure in terms of future tax policy-making in the SADC region but also opens an avenue for further tax co-operation efforts. J.E.L. Classification: H25, H32
\end{abstract}

Keywords: Corporate income tax rates; tax competition; tax co-operation; policy-making

\section{INTRODUCTION}

Corporations have become important generators of much needed tax revenue for the developing world, with Africa at the forefront. With the bulk of revenues collected from income taxes in developing countries, especially corporate taxes in some instances, the protection of the corporate tax base has become crucial. However, tax bases have become more mobile and governments' abilities to tax have deteriorated. The so-called "vanishing tax payer" or tax entity, has become a global force to be reckoned with (The Economist, 2000).

An understanding of the determinants of corporate taxes and more specifically corporate tax rates has become imperative. In this paper, the investigation is two-fold. The first group of determinants surrounds governments' abilities to generate tax revenue to finance domestic needs and thus government expenditure. The second group of determinants encompasses the downward pressure exerted on corporate tax rates by international competition for foreign direct investment. A cross-section panel (pooled and SUR) is utilised to find the main determinants or factors that best explain changes in corporate tax rates over time ${ }^{1}$. The so-called Seemingly Unrelated Regression or SUR is

- SARB College, South African Reserve Bank (previously Department of Economics, University of Pretoria). I wish to thank Iraj Abedian (Pan-African Investment and Research Services), Niek Schoeman (University of Pretoria), the Public Finance Division (SARB), and Sandra Mollentze (SARB College) for helpful comments and suggestions. I am also grateful to an anonymous referee and Philip Black for constructive and detailed comments on an earlier draft of the paper.

1 The paper is part of a broader research theme, namely to find evidence for the existence, but also the effects of tax competition in the SADC region. Although this theme has partly been addressed (Robinson, 2002), the ultimate goal is ongoing. Empirical work in terms of tax competition has (C) 2005 Economic Society of South Africa. Published by Blackwell Publishing, 9600 Garsington Road, Oxford OX4 DQ, UK and 350 Main Street, Malden, MA 02148, USA on behalf of ESSA. 
used as an added and unique methodology in this context.

This paper is divided into four sections. The next section provides a broad theoretical overview of the economic role and function that corporate tax serves within a global or regional context. Section 3 proceeds with an analysis of real world changes or trends and concentrates more specifically on the SADC ${ }^{2}$ region. Section 4 entails an empirical investigation that proposes an empirical model for explaining corporate tax rates in the region. Section 5 details policy issues and includes concluding remarks concerning research issues that still need to be addressed in future.

\section{THEORETICAL OVERVIEW}

The World Bank (1991) has recognised the importance of competitive responses on the part of developed regions to tax incentives in developing countries, the effectiveness of these incentives, and the need to harmonise taxes in developing regions. Tax policies have once again come under the spotlight with ten new members joining the European Union (EU). Low corporate tax rates are perceived as an obvious way of attracting investment and enhancing competitiveness, allowing the new members to achieve higher economic growth rates required to catch up with the original members (EU-15). Germany and France have called for tax harmonisation because of their concern about the low rates in several of the new member states.

Developing (emerging) regions tend to under-tax capital, especially the more elastic capital outflows. Adam Smith (1776) acknowledged that capital has never been the "citizen of any country". Tax havens ${ }^{3}$ have become a familiar site in order to avoid current and future taxes, and exchange controls. Whereas the OECD (1998) and the EU Code of Conduct $(1997$; 2004) lend credence to the claim of "harmful preferential tax regimes" and attempt to "blacklist" these countries or islands, Tanzi (1995) suggests the establishment of a World Tax Organisation to deal with global tax harmonisation issues.

Economic globalisation in conjunction with regional integration has led to various tax breaks for mobile capital, and technological change has made it difficult to tax capital (Gordon, 1992). The conventional view has always been that, if capital is mobile, tax competition will lead to a downward pressure on tax rates as well as an overestimation of the social marginal cost of public funds (SMFC) - additional revenue raised in one country, as a result of tax increases in another, will therefore not be forthcoming. Lower tax rates accross countries may in turn result in an inadequate supply of public services. Over time, individual countries have therefore lost some of their autonomy with respect to the setting of capital tax rates, and as such have become more dependent on immobile tax bases for income, such as land and domestic labour. Ricardo (1817) went further and reiterated that the expected future tax burden accompanying a high public debt would induce the rich and their capital to emigrate rather than to save. The so-called "Ricardian

only recently surfaced (see Slemrod, 2004; and Winner, 2005).

2 The Southern African Development Community (SADC) consists of the following member countries: Angola; Botswana; Democratic Republic of the Congo (DRC), Lesotho, Malawi, Mauritius, Madagascar, Mozambique, Namibia, South Africa, Swaziland, Tanzania, Zambia, and Zimbabwe.

${ }^{3}$ Ginsberg (1991: 15) provides a full account of taxation relief categories such as tax exemption (tax paradises or "no tax" havens), low taxation (tax shelters), special incentive privileges, tax exemption for manufacturing and processing of exports, and international CIT reduction 
equivalence" of debt and tax finance is therefore ironically rejected. Governments' tax abilities have become restricted with limited tax revenue forthcoming. This could either lead to a so-called "race to the bottom", or limit leviathan governmental growth. It might either lead to under-taxation and consequently an under-supply of government services, or to a natural process of tax rate convergence and thus a limitation on the growth of governments.

In a global society, where all governments have to compete on an equal footing regardless of their level of economic development, size or political agendas, it can happen that some countries, especially developing countries, push taxes too low without any regard for public needs. The outcome of low taxes, that is higher levels of capital investment, is also questionable in literature. Surely, especially in developing countries, public needs should take precedence over inefficient tax policies that generate uncertain revenue. So, is it the internal public needs that determine corporate tax or external competitive pressures? In the sections that follow we try to answer this question.

\section{(i) Tax competition and related literature.}

Tax competition is a competition in terms of tax bases and also effective tax rates. Effective tax rates, which are determined by statutory tax rates, the deductibility of interest, depreciation allowances, special investment incentives and the integration of personal and corporate income taxes, should thus be considered, and this in itself may be problematic. The effective tax rate for multinational investment is even more complicated. It depends on whether foreign sourced income is taxed in the host country, or in the home country of residence, or in both. The intricacies involved in the determination of the precise effects of changing taxes and at the same time changes in the tax base, are generally recognised (see UNCTAD, 1998).

Tax competition literature can be directly linked to the theory of optimal taxation and/or second-best theory (Frenkel, Razin and Sadka, 1991), and the aggregate production efficiency theorem (Diamond and Mirrless, 1971). Theorists extend the aggregate production efficiency theorem to an open economy context to include the desirability of source-based versus residence-based capital income taxes. The implication of the aggregate production efficiency theorem is that the source principle is always inferior to the residence principle. The latter principle guarantees the absence of distortions in individuals' investment and production choices (Dixit and Norman, 1980).

According to the source or territorial principle, income originating in the home region is uniformly taxed, regardless of the residency of the income recipient. Capital income is taxed only in the regions where it is produced, i.e. on the gross domestic product (GDP), and hence foreign-source income is tax exempt. The residence principle taxes residents of a region uniformly on their worldwide income, regardless of the source of that income. According to this principle all capital income of the investor (part od GNP of the region) is taxed, though tax credits/deductions may be provided (i.e. a hybrid residence principle).

\section{(ii) Zodrow and Mieszkowski (1986)}

The first amongst tax competition models include Zodrow and Mieszkowski (1986). They argue that inefficiently low tax rates and levels of public service provision are the result of competition for scarce capital. There are two regions involved. Each region, acting in isolation, is concerned that higher taxes on capital or property will drive out capital and lower its income (rent or wages) from land or labour. The main assumption is that each regional government's public expenditure must be financed by a tax levied on 
capital income earned within its boundaries, i.e. a source-based capital income tax. One reason for this assumption is that governments may find it administratively convenient to tax both capital and land at the same rate (uniform taxation). This case is based on local property taxation in the United States (US), which does however distort location decisions made by investors. Governments would therefore prefer a lump sum to a distortionary tax, even though the former may not be equitable.

A rise in a region's tax rate would benefit other regions (positive externality), through a capital outflow. Governments, of course, fail to account for such external benefits because they are only concerned with the welfare of their own residents. The tax rates and public service levels are therefore set at inefficiently low levels. The main proposition is that symmetric tax competition with source-based capital taxes, leads to inefficiently low capital tax rates and public goods supply in each country, relative to a situation where tax rates are coordinated.

(iii) Gordon (1986)

Gordon (1986) goes further and emphasises that a small, open economy should levy no distorting source-based taxes. In a small, open economy all taxes are normally borne by immobile factors (land and labour) and mobile factors earn the world rate of return. The incidence of a source-based tax will be identical to a labour tax, but the former will reduce capital stock in a way that the labour tax will not. Therefore, labour taxes should dominate, but do they?

In order to fully grasp the rationale, it is important to investigate investor behaviour when making investment choices and decisions. In terms of the residence (worldwide) principle, capital income is taxed in the country where the investor resides, irrespective of where the capital income has originated. Let the gross returns to capital or marginal product of capital (MPC) in two countries $i=\{A, B\}$ be denoted by $r^{i}$. A capital owner in country A comparing net returns from domestic and foreign investments will thus face the international arbitrage condition, numerically expressed as follows:

$\left(1-\mathrm{t}^{\mathrm{A}}\right) \mathrm{r}^{\mathrm{A}}=\left(1-\mathrm{t}^{\mathrm{B}}\right) \mathrm{r}^{\mathrm{B}} \Rightarrow \mathrm{r}^{\mathrm{A}}=\mathrm{r}^{\mathrm{B}}$

$\mathrm{MPC}^{\mathrm{A}}=\mathrm{r}^{\mathrm{A}}=\mathrm{r}^{\mathrm{B}}=\mathrm{MPC}^{\mathrm{B}}$ (thus encouraging capital export neutrality or CEN)

If $\mathrm{t}^{\mathrm{A}} \neq \mathrm{t}^{\mathrm{B}}$; net returns differ.

In terms of the source (territorial) principle, capital income is taxed in the country where the investment takes place, irrespective of the nationality of the investor. This will occur either where the residence country exempts the foreign-earned income from tax, or if they grant a limited tax credit and the tax rate in the host country exceeds the tax rate in the residence country of the investor. The international arbitrage condition can be numerically expressed as follows:

$\left(1-\mathrm{t}^{\mathrm{A}}\right) \mathrm{r}^{\mathrm{A}}=\left(1-\mathrm{t}^{\mathrm{B}}\right) \mathrm{r}^{\mathrm{B}} \Rightarrow \mathrm{r}^{\mathrm{A}}=\mathrm{r}^{\mathrm{B}} \Rightarrow$ gross-of-tax returns and MPCs will differ

$\mathrm{MPC}^{\mathrm{A}}=\mathrm{r}^{\mathrm{A}} \neq \mathrm{r}^{\mathrm{B}}=\mathrm{MPC}^{\mathrm{B}}$ (encourages capital import neutrality or CIN)

If $\mathrm{t}^{\mathrm{A}} \neq \mathrm{t}^{\mathrm{B}}$; net returns are equalised.

Developing countries must consider that the source basis resembles the benefit principle, and the residence principle the ability-to-pay, i.e. countries with high foreign income are normally on the residence principle, and those with low foreign income on the source principle where administrative expediency is of utmost importance. Tax systems should ensure tax neutrality, i.e. it should not influence locational decisions. The source principle is neutral to capital imports (CIN) and does not discriminate between domestic and 
foreign investment. Developing countries tend to be capital importers. The residence principle is neutral to capital exports $(\mathrm{CEN})$ and this ensures that the investor pays the same total income tax (domestic plus foreign), whether he receives the given investment income from foreign or from domestic sources (i.e. apart from different tax rates). Foreign and domestic activities bear the same amount of tax on their income.

Most countries tend to be on a mix of both systems, i.e. a hybrid system, with double taxation still problematic. In most countries that operate on the residence principle, individuals pay local income taxes, irrespective of nationality, i.e. it operates as source principle on direct investment, but residents (companies incorporated \& individuals) pay on worldwide income from all sources. Bilateral tax treaties or harmonising the tax treatment of cross-border income provide in part a solution. It is normally difficult to harmonise taxation on a multilateral basis, because countries perceive net benefits of each system differently. The same arguments hold for the SADC region, where most countries operate on the source principle (Appendix B, Table B.1).

It is argued that the residence principle is more efficient than the source principle, even in the presence of different tax rates or tax competition. Taxes are the same on foreign and domestic income. This is in line with the idea that a country can maximise its revenue by taxing its residents on the basis of their worldwide income, whilst striving for interpersonal equity via progressive taxation (Musgrave, 1990). As already mentioned, the residence principle allows capital export neutrality (CEN) that implies that the tax system does not affect the choice between investing at home or abroad, i.e.it is non-distortionary. Both of these objectives, revenue maximisation and CEN, are also pursued by the double-taxation relief treaty (OECD, 1977). This treaty calls for the primary taxation of portfolio income by residence countries of creditors and shareholders. It therefore encourages source countries to levy low withholding taxes on interest and dividends paid to foreigners. Taxpayers with a high tax bill on their worldwide income can, however, migrate, and domestic firms can seek an alternative "tax address" through a tax haven.

(iv) Other

The importance of the argument that tax competition can be efficient, even in the absence of residence-based taxation (see also Bucovetsky and Wilson, 1991), relates in effect to the fact that the application of the residence principle gives rise to all kinds of problems (e.g. administration and compliance costs particularly in terms of foreignsourced income). In an open economy, governments often cannot fully tax foreign source income due to capital flight (tax evasion), or the manipulation of transfer prices within multinational corporations. Governments are not always inclined to report to foreign fiscal authorities on, for instance, income from those residents investing abroad (Baccheta and Espinosa, 1992 and 1995). Instead, the host fiscus has a strong incentive to tax nonresidents for the reason mentioned above (a source-based approach). Much empirical evidence has been provided in terms of tax enforcement problems (tax evasion) and thus the survival of capital income taxes (Gordon, 1992).

Frenkel, Razin and Sadka (1991:214-216) argue that no capital income tax whatsoever should be levied, if capital flight cannot be effectively stopped. Welfare, however, may increase by imposing capital controls that could, at least to some extent, reduce taxmotivated capital flight. Even if an investment-neutral tax is available, a government may use distortionary taxes to influence the investment or production choices of firms. This may happen under conditions of of imperfect competition when firms have market power in the output market, or governments manipulate the terms of trade in the capital 
market (Janeba, 1994).

In the next section we provide an overview of the prevailing situation in the SADC region after which an attempt will be made to partly test the theoretical arguments already discussed.

\section{THE PREVAILING SITUATION IN THE SADC REGION: DATA ISSUES}

Before attempting to explain the data, it is important to discuss prominent features of the tax structure in the SADC region. In terms of capital income tax, the share of corporate tax revenues in total taxes at the central or national level in SADC member countries are relatively low (excluding the Democratic Republic of the Congo and South Africa), compared to those at the sub-national level in Argentina, Brazil and India ${ }^{4}$.

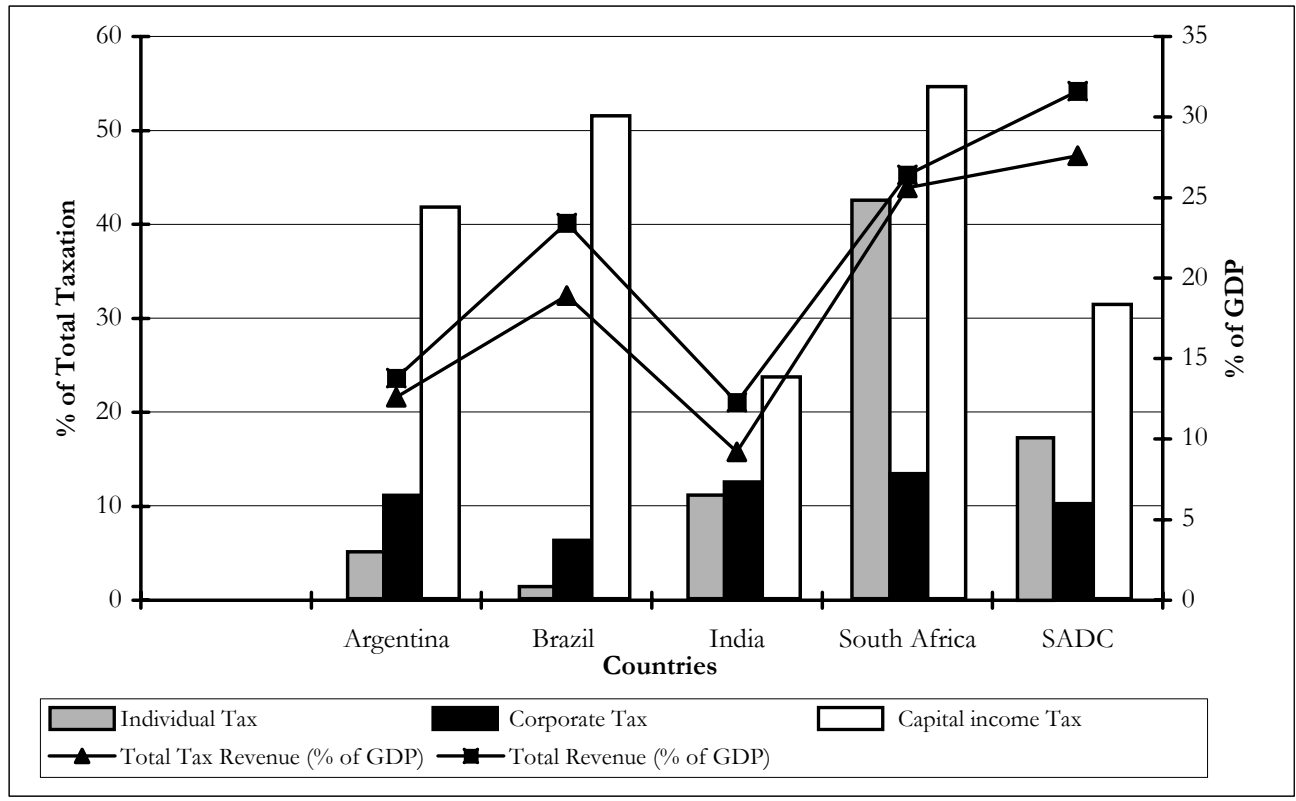

Figure 1. Capital income Tax in Selected Federations and the SADC

Source: Own estimates based on CREFSA (1998), FISCU (1999), IMF (2000) and members' contributions.

In terms of the national level, the SADC member countries compare well with the selected countries (Fig. 1). In the latter countries the individual income taxes collected are significantly larger at sub-national level, than the corporate taxes collected. In the case of the SADC region, the opposite is true regarding the national level. The individual income taxes collected are significantly larger at national level than the corporate taxes collected, with the exception of Botswana and the DRC.

\subsection{Corporate versus individual income tax burdens}

The bulk of revenues of developing countries come from income taxes, mainly corporate

4 These countries are relevant examples because of their federal, but also developmental status. Although Fig. 1 represents taxes at federal level for the countries in question, they apply subnational corporate taxes. The idea is to draw comparisons between the sub-national levels of the selected federations and the national levels of the SADC member countries, to form a preconceived picture of a future, fully-integrated SADC region. 
taxes, that is generally at a level of 6 per cent of GDP and 38 per cent of total revenue (Burgess and Stern, 1992; Black et al. 1999). However, levels of taxation normally relate to the levels of development in countries. The level of development determines the size of the tax base, but also has an effect on a country's capacity to administer taxes. Varying degrees of development can be observed within the SADC region. Countries such as Angola, the DRC, Lesotho, Malawi, Mozambique, Tanzania, Zambia, and Zimbabwe are classified as low-income developing countries. Countries such as Namibia, South Africa and Swaziland are classified as lower middle-income developing countries with Botswana and Mauritius as upper middle-income countries. Although South Africa is classified as a lower middle-income developing country, it is important to note that the main reason for this is the unequal income distribution within the country, and that this economy is mostly classified as more developed by organisations such as UNCTAD. Although some of the SADC members (Mozambique, Tanzania, Zambia, Zimbabwe and South Africa) have started with improved tax administration efforts in order to broaden their tax base, the full potential of the region still needs to be explored.

Another possible explanation for the higher individual income tax burden in the SADC region could relate to the shift in tax burdens away from corporate tax burdens (internationally mobile tax bases) to individual income tax burdens and commodity tax burdens (perceived as the less mobile tax bases). A disconcerting feature relates to the fact that in some countries, notably South Africa and Zimbabwe, this shift has only taken place from an overall reliance on corporate taxes to individual taxes. With labour becoming more mobile, especially skilled labour from developing countries (World Bank, 2000) and general consumption taxes becoming the fastest growing revenue sources worldwide, it is almost a certainty that individual income tax as revenue source will reduce in importance going forward.

Further, the average share of capital income taxes as percentage of total taxation in the SADC is already quite high (31.3 per cent), but room for improvement exists if compared with the EU average (41.6 per cent). The attraction of passive and active investment, specifically in developing countries (mostly capital-importing in nature), have increasingly become important and corporate tax burdens have therefore been kept artificially low, with high individual income tax burdens.

\subsection{Effective tax burden}

A further reason for the lower corporate tax burden, as opposed to the individual income tax burden in the SADC region, relates to the effective tax burden in the region. The effective tax burden refers to various aspects concerning the decision to to invest (specifically the user cost of capital). The effective tax rate of a corporation is normally a complex - Titia, please close this gapfunction of the statutory tax rate on corporate income, the extent of double taxation relief and the definition of the tax base (operating surplus), including the system of depreciation (King and Fullerton, 1984; OECD, 1991; Razin and Sadka, 1993). Aspects normally included or investigated in such a calculation are:

- Tax expenditures;

- The extent of "carry back" or "forward" actions in terms of trading losses;

- High debt:equity ratios;

- Deductions for nominal interest costs;

- Under-reporting of profits;

- Transfer pricing; 
- Using special and tax incentives'

- Accounting practices in terms of the treatment of inventories (FIFO or LIFO); and

- Exploitive measures in terms of administrative weaknesses of tax collecting authorities.

Withholding taxes, income exemption, special allowances, deductions and investment schemes become relevant in terms of the above-mentioned calculation (Appendix B, Table B.1). In this paper, the empirical analysis does not cover effective tax rates. Although the utilisation of the statutory tax rate on its own could be misleading, the statutory tax rate remains important for profit shifting operations by multinational corporations. The issue is compounded by data constraints, in the sense that essential information concerning the tax base (operating surplus) is not available. In summary, it is impossible to capture all details concerning a tax system that could potentially affect or could be affected by investment in an empirical analysis.

\subsection{Changes in CIT-rates over time}

In order to get an overall picture of the changing patterns and tendencies in CIT, the mean and standard deviation of the statutory and average tax rates are shown in Table 1. The average tax rates represent the ratio of CIT revenues to GDP.

Table 1. Changes in CIT-rates in the SADC region, 1980-2004

\begin{tabular}{lllll}
\hline Years & $\begin{array}{l}\text { Statutory rate } \\
\text { Mean }\end{array}$ & $\begin{array}{l}\text { S.D. } \\
\text { Average rate }\end{array}$ & Mean \\
$1980-1985$ & 0.443182 & 0.054876 & 0.044532 & 0.026105 \\
& 0.453864 & 0.057024 & 0.045930 & 0.028886 \\
$1980-1990$ & 0.443182 & 0.054876 & 0.044532 & 0.026105 \\
& 0.412833 & 0.076514 & 0.034851 & 0.034851 \\
$1980-1995$ & 0.443182 & 0.054876 & 0.040000 & 0.019357 \\
& 0.361667 & 0.054171 & 0.042544 & 0.034047 \\
$1985-1990$ & 0.453864 & 0.057024 & 0.054208 & 0.028886 \\
& 0.412833 & 0.076514 & 0.059789 & 0.034851 \\
$1985-1995$ & $\mathbf{0 . 4 5 3 8 6 4}$ & $\mathbf{0 . 0 5 3 6 8 5}$ & 0.054208 & 0.019041 \\
& $\mathbf{0 . 3 6 1 6 6 7}$ & $\mathbf{0 . 0 5 4 1 7 1}$ & 0.042544 & 0.034047 \\
$1990-1995$ & 0.412833 & 0.076514 & 0.059789 & 0.034851 \\
& 0.361667 & 0.054171 & 0.042544 & $\mathbf{0 . 0 3 4 8 5 1}$ \\
$1990-2000$ & 0.412833 & 0.076514 & $\mathbf{0 . 0 5 9 7 8 9}$ & $\mathbf{0 . 0 1 4 3 4 1}$ \\
& 0.330333 & 0.068517 & $\mathbf{0 . 0 2 0 9 0 0}$ & 0.034851 \\
$1990-2004$ & 0.412833 & 0.076514 & 0.059789 & 0.014341 \\
$2000-2004$ & 0.323667 & 0.068725 & 0.020900 & 0.014341 \\
\hline
\end{tabular}

Source: Author's calculations for different sets of country-year observations.

The methodology used in Table 1 is similar to that of Slemrod (2004) and various other authors, with some minor adjustments. It is important to recall sections 3.1 and 3.2 and remember to continuously take all shortcomings into consideration when utilising statutory CIT-rates. Each pair of 5-year intervals between 1980 and 2004 is done only for those countries for which data is available for the beginning and ending of a year.

It can be observed that developing regions such as SADC closely followed declining tendencies that occurred in statutory CIT-rates since 1985 in the industrialised world. Between 1985 and 1995 the mean statutory rate fell sharply from 45 to 36 per cent, which continued into the 1990-1995 interval. The dispersion in these rates was at its highest in the latter interval, but started to stabilise during the 1990-2004 interval. For the average CIT-rates, the largest decline in the mean and standard deviation occurred during 19902000, with the standard deviation stabilising from 2000-2004.

\section{AN EMPIRICAL MODEL FOR EXPLAINING CIT-RATES}

The discussion thus far suggests a general empirical/prospective model explaining the 
impact of various independent variables on (1) the statutory CIT-rate and (2) the average CIT-rate, which could accept the following mathematically form:

$$
\begin{aligned}
& C I T_{i t}=\mu_{i}+\lambda_{t}+\beta_{1} X_{1}+\beta_{2} X_{2}+\beta_{3} X_{3}+\beta_{4} X_{4}+\beta_{5} X_{5}+\beta_{6} X_{6}+\beta_{7} X_{7}+\ldots \varepsilon_{i t} \mu \\
& A V G C_{i t}=\mu_{i}+\lambda_{t}+\beta_{1} X_{1}+\beta_{2} X_{2}+\beta_{3} X_{3}+\beta_{4} X_{4}+\beta_{5} X_{5}+\beta_{6} X_{6}+\beta_{7} X_{7}+\ldots \varepsilon_{i t} \mu
\end{aligned}
$$

where $\mu$ is the country dummy that represents country specific factors; $\lambda$ is the time dummy that represents the change over time; $\beta$ represents the different coefficients, in all approximately eight; and $X$ is the different $\mathrm{SADC}^{5}$ members involved.

In the SADC region an array of fiscal measures are still present and this can generate effective tax rates on investment that deviate from zero and can be highly variable across assets and sectors. These effective tax rates are not transparent and it is therefore difficult to determine whether the resulting implicit structure of corporate tax incentives corresponds in any way to policy intentions. The mining sector is an example of this. Throughout the SADC, the mining sector receives special allowances; for instance, in Angola and the DRC lower CIT-rates are applicable on oil contractors. In these cases the effective tax rates would be much lower than the statutory rate of taxation, and possibly even negative. A reduction in the statutory rate is a standard recommendation to attract investment. However, a reduction in the statutory rate would lower effective tax rates, even if no investment were actually forthcoming. This reduction would entail a windfall gain to the owners of the existing stock of capital and a loss of revenue for revenue authorities even if no investment takes place.

An alternative procedure would entail an increase of allowances granted at the time of investment. It would thus only be activated in the event of new investment. The loss of current revenue would therefore only take place if the investment actually takes place. Further, since the incentive is received at the time of investment, it cannot subsequently be taken back, i.e. commitment problems could be avoided. In effect it reduces the investor's uncertainty regarding the present value of his tax obligations. In the case of lower statutory rates applied to a specific sector such as mining and/or manufacturing, discrimination between the different sectors can easily be detected but often the structure of allowances, differential rates and tax holidays are so complex that the ultimate effect on incentives is difficult to identify (Appendix B, Table B.1). This kind of discrimination leads to a distortion in the allocation of investment and therefore affects distribution and equity. All sector-specific and all -asset-specific incentives, other than those related to depreciation, should therefore rather be avoided.

Instead of utilising our two dependent variables, namely the statutory and average tax rate, one could have used a parameter that represents the effective tax rate on new investment by the recipient country and the tax rate of the home country. The absolute value of corporate tax in a specific SADC member, for instance South Africa, and its biggest trade partners, for instance the United Kingdom, could then have been expressed as a ratio to the respective countries' GDP, with a series consisting of the differential

\footnotetext{
${ }^{7}$ In 2004, the Seychelles withdrew as a SADC member. The country was, however, included in the analysis because of the applicable time frame. It is also worth noting that although Madagascar was excluded from the analysis, it became a SADC member in August 2005.
} 
between the two ratios. This exercise, however, is of an entirely different nature, and separate time-series analysis would have to be performed for most SADC members. Data limitations in some instances should also be taken into account, if any such study is attempted.

The data sets used were mostly obtained from the International Financial Statistics (Government Financial Statistics), and the World Bank (Appendix A). The panel covers the period 1980 to the end of 2000. The first columns of Tables 2 and 3 below show the results for assessing country specific trends over time in corporate tax. It includes the Seemingly Unrelated Regression (SUR) of the two tax rate measures on country and time dummies, for 1985, 1990, 1995, and 2000, plus a constant term. These tendencies show similar results to that obtained in Table 1. Developing regions such as SADC closely followed declining tendencies in CIT-rates, as observed in the industrialised world. Between 1985 and 1995 the statutory and average rate fell, but this continuous fall only gained momentum or significance from 1995 onwards.

Various econometric techniques have been tried and tested beforehand in order to find the most suitable for the study at hand. Firstly, it was found that a pooled model is the most restrictive of all of the specifications and does not acknowledge any cross-section heterogeneity within the SADC region, assuming a common intercept for the whole panel. Secondly, the so-called fixed-effects model acknowledges cross-section heterogeneity and assumes a different intercept for each country included in the sample. It achieves this by including a matrix of dummies in the estimation in the case of the LSDV estimator. In the case of the WITHIN estimator, cross-section effects are wiped out, essentially estimating the same coefficients but running the regression though the origin. Thirdly, the random effects model also acknowledges the cross section heterogeneity but differs from the fixed effects models in that these effects are generated by a specific distribution. Finally, the Seemingly Unrelated Regression or SUR analysis (see Zelner, 1962) that takes fixed effects into account was decided upon. This technique is rarely utilised in international studies of this nature, and as such the study represents an added and unique effort in the sense that it also incorporates country dummy variables. A model may contain a number of linear equations, but it would be unrealistic to expect that the equation errors are uncorrelated. A set of equations that has contemporaneous crossequation error correlation is called a Seemingly Unrelated Regression (SUR) system. At first look, the equations seem unrelated, but the equations are related through the correlation in the errors.

Tables 2 and 3 show the results concerning the statutory and average CIT-rates, respectively. The first column shows the results with only time dummies included, as discussed above 6 . Time dummies and country dummies are included in all subsequent analyses, so that the regressions explain the variation in the tax measures relative to yearly averages, but also country averages over the specific time period. The estimated coefficients on the time dummies refer to the variations for a given year that are not explained by the changes over time in other independent variables. In the same fashion, the estimated coefficients on the country dummies refer to the variations for a given country that are unexplained by the changes over time in other independent variables.

\footnotetext{
${ }^{8}$ The number of observations is much higher in column (1) of Tables 2 and 3 , in comparison with the regressions that follow. This is mainly due to the unavailability of some of the other independent variables.
} 
The first pair of regressions is pooled least-squares regressions, with the first pair having only the internal and/or regional variables (column 2), and the second pair having both internal and external (international) variables (column 3).

The pairs in columns 4 and 5 also have country dummy variables, although the country-specific coefficients are not reported. These are fixed effects estimators (from there the answer "yes" on country fixed effects in columns 4 and 5) and as already mentioned, explain the changes in the tax measures relative to the country averages as well as the year averages. The fixed effects methodology is especially valuable if one suspects that there are unmeasured determinants (differences in political, institutional and economic policy systems) of a country's statutory and average rate. For both the dependent variables, fixed effects mainly occurred for the following countries: Democratic Republic of the Congo (DRC), Lesotho (LES), South Africa (SA), Zambia (ZAM), and Zimbabwe (ZIM). The SUR analysis makes provision for any further unexplained factors through acknowledging the error term. If any linkages (information) exist between countries that irreversibly bond the countries through common grounds, which would most probably be the case for an economic block such as SADC, the SUR analysis would account for these. Common factors could, for instance, include high HIVAIDS infection ratios, and high absolute poverty levels.

All results delivered excellent R-squares, i.e. well-fitted or explained models. The explanatory power of the independent variables ${ }^{7}$ in terms of the applicable dependent variable was therefore good (see Tables 2 and 3).

\subsection{Statutory CIT-rates}

The empirical results in this paper are interesting, and in some instances, surprising. The personal income tax rate variable is significant at a 1 per cent level throughout. The backstop scenario is therefore applicable in this paper, i.e. that the statutory CIT-rate is directly linked to what happens with the personal income tax rate in a country. This makes perfect sense because in countries such as South Africa, the Ministry of Finance or the National Treasury (NTSA) has continuously attempted to bridge the gap between the PIT- and CIT-rate. It therefore makes sense to accept that in countries with a higher PITrate, the statutory CIT-rate will also be higher.

As already pointed out earlier, various tax reform measures have been implemented to try and avoid the reclassification of labour income as business income. The gap between the CIT-plus STC-rate and the highest marginal PIT-rate has become much smaller. The PITNOCAP variable basically explains that if there is no capital gains tax, the PIT-rate is applied. In most of the countries capital gains tax is present. This variable is highly significant (column 5) and implies that if the capital gains tax rate increases, the CIT-rate will decline. The same scenario goes for the dummy indicator of available/missing information (INDMISS), and this will obviously concur with the PITNOCAP.

In the SADC region, where withholding tax rates (from 5 to 25 per cent depending on the type of income involved) are still of utmost importance and double taxation agreements are rare or non-existent (South Africa has the most extensive list of all SADC countries), it is not surprising that a strong negative relationship is present in terms of CIT-rates. This could mean that those countries need to adjust their CIT-rates downwards when withholding tax rates move in the opposite direction. This is naturally

\footnotetext{
7 Other independent variables such as government deficits and foreign direct investment (FDI) were also included, but in most cases with no significant results.
} 
not applicable for industrialised countries where endless lists of double taxation agreement are already in place. Another variable that is also related in this context is the dummy that considers whether the country is on a source or residence (SR) system, but this variable has proven to be completely insignificant.

The government expenditure-to-GDP ratio is positively (though insignificantly) related with the CIT-rate in the pooled estimation (column 2), where only internal and/or regional variables are included. The electrification variable is mostly negatively related to the CIT-rate and this could be an indication of the level of development, in the sense that improved service delivery could mean lower CIT-rates. However, some corporations would rather pay more and be assured of continuous quality services. The OIL/MINERAL variable turns out to be insignificant, and it could simply mean that oil or mineral production does not explain how the statutory rate is being determined. It should, however, be noted that when individual estimations were run for the different countries separately, this variable delivered significant results for some countries, e.g. Botswana (diamonds), DRC and South Africa (gold/platinum).

Table 2. Regressions in terms of the statutory CIT-rate

\begin{tabular}{|c|c|c|c|c|c|}
\hline & 1 & 2 & 3 & 4 & 5 \\
\hline Year (1985) & $\begin{array}{c}-0.0087 \\
(0.4370)\end{array}$ & $\begin{array}{c}0.0135 \\
(0.6353)\end{array}$ & $\begin{array}{c}0.0114 \\
(0.7947)\end{array}$ & $\begin{array}{l}-0.0076 \\
(0.3710)\end{array}$ & $\begin{array}{l}-0.0285 \\
(0.6370)\end{array}$ \\
\hline Year (1990) & $\begin{array}{l}-0.0247 \\
(1.3645)\end{array}$ & $\begin{array}{c}0.0284 \\
(1.3449)\end{array}$ & $\begin{array}{c}0.0087 \\
(0.2481)\end{array}$ & $\begin{array}{l}-0.0367 \\
(1.1235)\end{array}$ & $\begin{array}{l}-0.0649 \\
(1.5642)\end{array}$ \\
\hline Year (1995) & $\begin{array}{c}-0.0583 \\
(3.1412)^{*}\end{array}$ & $\begin{array}{c}0.0187 \\
(0.6899)\end{array}$ & $\begin{array}{l}-0.0159 \\
(0.4168)\end{array}$ & $\begin{array}{c}-0.0566 \\
(2.1412)^{*}\end{array}$ & $\begin{array}{c}-0.1586 \\
(3.1412)^{* *}\end{array}$ \\
\hline Year (2000) & $\begin{array}{c}-0.0656 \\
(2.7653)^{*}\end{array}$ & $\begin{array}{c}0.0185 \\
(1.8567) \\
\end{array}$ & $\begin{array}{c}-0.0510 \\
(2.4165)^{* *}\end{array}$ & $\begin{array}{c}-0.0256 \\
(4.7653)^{*}\end{array}$ & $\begin{array}{c}-0.0145 \\
(2.7653)^{* *}\end{array}$ \\
\hline $\begin{array}{l}\text { PIT } \\
\end{array}$ & & $\begin{array}{c}0.3159 \\
(8.6227)^{*}\end{array}$ & $\begin{array}{c}0.3774 \\
(4.9491)^{*}\end{array}$ & $\begin{array}{c}0.3251 \\
(4.6612)^{*}\end{array}$ & $\begin{array}{c}0.3962 \\
(9.6551)^{*}\end{array}$ \\
\hline PITNOCAP & & $\begin{array}{c}-0.005 \\
(0.0814)\end{array}$ & $\begin{array}{l}-0.0476 \\
(0.2486)\end{array}$ & $\begin{array}{c}0.0483 \\
(0.6798)\end{array}$ & $\begin{array}{c}-0.1310 \\
(-4.5531)^{*}\end{array}$ \\
\hline INDCMISS & & $\begin{array}{c}0.0352 \\
(0.7992) \\
\end{array}$ & $\begin{array}{l}-0.0037 \\
(0.1235) \\
\end{array}$ & & $\begin{array}{c}-0.0166 \\
(-2.8063) *\end{array}$ \\
\hline GOVEXP & & $\begin{array}{c}0.2278 \\
(2.3480)^{* *}\end{array}$ & $\begin{array}{c}0.0875 \\
(1.4266)\end{array}$ & $\begin{array}{c}-0.0525 \\
(-0.9255)\end{array}$ & $\begin{array}{c}0.0200 \\
(1.3987)\end{array}$ \\
\hline $\mathrm{W}$ & & & & $\begin{array}{c}-0.4531 \\
(-2.3562)^{* *}\end{array}$ & $\begin{array}{c}-0.4070 \\
(-7.8776) *\end{array}$ \\
\hline SR & & & & $\begin{array}{l}-0.01897 \\
(-0.8170)\end{array}$ & $\begin{array}{c}0.0042 \\
(0.9254)\end{array}$ \\
\hline OIL/MINERAL & & $\begin{array}{c}0.1554 \\
(0.7234)\end{array}$ & $\begin{array}{c}1.5658 \\
(0.7381)\end{array}$ & & $\begin{array}{c}0.0584 \\
(1.72481)\end{array}$ \\
\hline ln_ELEC & & $\begin{array}{c}-0.0149 \\
(2.5246)^{*}\end{array}$ & $\begin{array}{c}0.0054 \\
(0.7697)\end{array}$ & & $\begin{array}{c}-0.0028 \\
(-2.4191)^{* *}\end{array}$ \\
\hline In_POP & & & $\begin{array}{c}0.006 \\
(1.2441)\end{array}$ & & $\begin{array}{c}-0.3825 \\
(-0.7508)\end{array}$ \\
\hline $\mathrm{O}$ & & & $\begin{array}{c}-0.0756 \\
(-2.8147)^{* *}\end{array}$ & & $\begin{array}{c}-0.3962 \\
(-8.74214)^{*}\end{array}$ \\
\hline Constant & $\begin{array}{c}0.4674 \\
(24.7654)^{*}\end{array}$ & $\begin{array}{c}0.3765 \\
(4.7980)^{*}\end{array}$ & $\begin{array}{c}0.1257 \\
(1.2459)\end{array}$ & $\begin{array}{c}3.4888 \\
(4.3290) *\end{array}$ & $\begin{array}{c}3.57921 \\
(3.6902)^{*}\end{array}$ \\
\hline Country fixed effect & No & No & No & Yes & Yes \\
\hline Observations & 226 & 191 & 159 & 191 & 159 \\
\hline $\mathrm{R}^{2}$ & 0.8888 & 0.8844 & 0.8914 & 0.8785 & 0.8914 \\
\hline
\end{tabular}

Note:* t-statistic significant at $1 \%$ level ** t-statistic significant at $5 \%$ level

The population variable (In_POP), indicating the size of the country or region and partly relating to tax competition literature, turns out to be insignificant in all cases. The presence-of-trade variable $(\mathrm{O})$ is determined as follows: [Exports $(\mathrm{X}) / \mathrm{Gross}$ Domestic Product (GDP) + Imports (Z)/Gross Domestic Expenditure (GDE)]/2. It partly gives an indication of trade openness in the region. This variable is negatively associated with 
the CIT-rate, both for the pooled and SUR (fixed-effects) estimators, where all international variables are present.

Although this result could be indicative of lower CIT-rates with higher trade ratios and therefore international pressure to lower CIT-rates, it should be read with caution because other factors also play a definite role in terms of a country's openness.

In terms of openness, the withholding taxes applicable to residents and non-residents differ substantially across the region. These taxes provide also for an exemption of dividends, especially for residents, or higher rates on dividends for non-residents. Withholding rates therefore differ substantially within a band of 0 to 33 per cent on residents, and 0 to 36 per cent on non-residents, all depending on the specific income involved. Discrimination between resident and non-resident individuals and corporations are therefore nothing strange to the SADC region (see Appendix B, Table B.1).

\subsection{Average CIT-rates}

In this section average CIT-rates are calculated as actual corporate income tax revenues, expressed as ratios of GDP. The PIT-rate only becomes significant (at a 5 per cent level) in the pooled estimation, where international variables are also taken into account. The backstop rule is therefore again applicable only to a certain extent.

Table 3. Regressions in terms of the average CIT-rate

\begin{tabular}{|c|c|c|c|c|c|}
\hline & 1 & 2 & 3 & 4 & 5 \\
\hline Year (1985) & $\begin{array}{l}0.0157 \\
(0.5370)\end{array}$ & $\begin{array}{l}0.2135 \\
(0.7353)\end{array}$ & $\begin{array}{l}0.2114 \\
(0.8947) \\
\end{array}$ & $\begin{array}{l}0.0176 \\
(0.2710) \\
\end{array}$ & $\begin{array}{l}0.0084 \\
(0.4370)\end{array}$ \\
\hline Year (1990) & $\begin{array}{l}0.0347 \\
(1.3745)\end{array}$ & $\begin{array}{l}0.0445 \\
(1.3459)\end{array}$ & $\begin{array}{l}0.1087 \\
(0.5481)\end{array}$ & $\begin{array}{l}-0.1467 \\
(-1.2235)\end{array}$ & $\begin{array}{l}-0.5247 \\
(-1.3645)\end{array}$ \\
\hline Year (1995) & $\begin{array}{l}-0.0583 \\
(-3.1523)^{*}\end{array}$ & $\begin{array}{l}0.0197 \\
(0.7199)\end{array}$ & $\begin{array}{l}-0.5159 \\
(-0.3168)\end{array}$ & $\begin{array}{l}-0.1866 \\
(-3.1432)^{*}\end{array}$ & $\begin{array}{l}-0.2583 \\
(-3.1412)^{*}\end{array}$ \\
\hline Year $(2000)$ & $\begin{array}{l}-0.0756 \\
(-3.7653)^{*}\end{array}$ & $\begin{array}{l}0.0285 \\
(0.9567)\end{array}$ & $\begin{array}{l}-0.1510 \\
(-0.6165)\end{array}$ & $\begin{array}{l}-0.1256 \\
(-3.7653)^{*}\end{array}$ & $\begin{array}{l}-0.3656 \\
(-2.6547)^{\text {** }}\end{array}$ \\
\hline PIT & & $\begin{array}{l}-0.0141 \\
(-0.0529) \\
\end{array}$ & $\begin{array}{l}0.5057 \\
(2.1301)^{* *}\end{array}$ & $\begin{array}{l}-0.0155 \\
(-0.5745)\end{array}$ & $\begin{array}{l}-0.0127 \\
(-0.4725)\end{array}$ \\
\hline PITNOCAP & & $\begin{array}{l}-0.0385 \\
(-0.3537)\end{array}$ & $\begin{array}{l}-0.1467 \\
(-1.4057) \\
\end{array}$ & $\begin{array}{l}0.0720 \\
(2.1434)^{* *}\end{array}$ & \\
\hline GOVEXP/DEFICIT & & $\begin{array}{l}0.1779 \\
(1.0397)\end{array}$ & $\begin{array}{l}-0.93 /-0.02 \\
(-2.3 /-2.25)^{* *}\end{array}$ & $\begin{array}{l}-0.0294 \\
(-0.8105)\end{array}$ & $\begin{array}{l}-0.0385 \\
(-2.5567)^{* *}\end{array}$ \\
\hline W & & $\begin{array}{l}0.6152 \\
(-2.7567)^{* *}\end{array}$ & $\begin{array}{l}-0.3767 \\
(-2.3155)^{* *}\end{array}$ & & $\begin{array}{l}-0.2022 \\
(-3.2426)^{*}\end{array}$ \\
\hline SR & & $\begin{array}{l}-0.1099 \\
(-1.1776)\end{array}$ & $\begin{array}{l}0.3151 \\
(1.8935)\end{array}$ & & \\
\hline OIL/MINERAL & & $\begin{array}{l}8.9955 \\
(1.3759) \\
\end{array}$ & $\begin{array}{l}9.3487 \\
(6.15267)^{*}\end{array}$ & & $\begin{array}{l}0.0831 \\
(2.8598)^{* *}\end{array}$ \\
\hline ln_ELEC & & $\begin{array}{l}0.6152 \\
(2.0171)^{* *}\end{array}$ & $\begin{array}{l}-0.6915 \\
(-7.2773)^{*}\end{array}$ & & $\begin{array}{l}0.0712 \\
(5.7481)^{*}\end{array}$ \\
\hline In_POP & & & & & $\begin{array}{l}-0.0420 \\
(-3.2961)^{* *}\end{array}$ \\
\hline $\mathrm{O}$ & & & $\begin{array}{l}0.1712 \\
(0.5969)\end{array}$ & & $\begin{array}{l}0.1347 \\
(3.9992)^{*}\end{array}$ \\
\hline Constant & $\begin{array}{l}-0.0534 \\
(-7.4124)^{*}\end{array}$ & $\begin{array}{l}-25.1901 \\
(-4.7980)^{*}\end{array}$ & $\begin{array}{l}-15.0415 \\
(-7.0783) *\end{array}$ & $\begin{array}{l}-0.0848 \\
(-2.3549) * *\end{array}$ & $\begin{array}{l}-0.0400 \\
(-2.4948)^{* *}\end{array}$ \\
\hline Country fixed effect & No & Yes (GLS) & No (Pooled) & Yes & Yes \\
\hline Observations & 203 & $70-124$ & $58-115$ & 124 & 115 \\
\hline $\mathrm{R}^{2}$ & 0.6900 & $0.66-0.96$ & 0.8856 & 0.8301 & 0.8914 \\
\hline
\end{tabular}

Note: ${ }^{*}$ t-statistic significant at $1 \%$ level ${ }^{* *}$ t-statistic significant at $5 \%$ level.

In this case, it means that for every percentage increase in the PIT-rate, the average CITrate will increase by 0.51 percentage points. In this sense it again makes perfect sense that these countries will raise more CIT-revenues when PIT-rates soar, because of the direct link between the two rates.

The PITNOCAP variable is significant at a 5 per cent level in the SUR/fixed-effects 
analysis, where no international variables (column 4) are considered. However, this relationship now becomes positive whereas previously it was negative (see Table 2), and implies that if the capital gains tax rate increases, the average CIT-rate, that partly links with the amount of revenues raised, will increase.

Surprisingly the government expenditure variable (in this case the deficit as a ratio of the GDP, was also tested) is negatively related at a 5 per cent level of significance in both cases where international variables are in place (columns 3 and 5) . Although the coefficients are mostly rather small, the result does refute the idea that lower taxes result in a lower supply of public goods, i.e. tax competition reduces public spending. The result could also relate to the extent of electrification that delivers a similar result for column 3. In terms of withholding tax rates, for the same reasons as explained under section 4.1, a strong negative relationship exists in terms of the average CIT-rates. Again the SR-variable is insignificant.

As for the OIL/MINERAL variable, the result becomes highly significant, positively related for both the pooled and SUR-analysis, where international variables are included (columns 3 and 5). This confirms this region's dependency on mineral production to generate tax revenues.

The population variable (ln_POP) now becomes significant, but the coefficient is small in relation to other variables. The presence-of-trade $(\mathrm{O})$ variable is positively associated with the CIT-rate for fixed effect (SUR) estimators, where international variables are present. This tends to confirm the region's dependence also on trade for tax revenues and possibly also its ability to attract tax revenues from capital flows (see also Garrett, 1995; Quinn, 1997; Amusa, 2004; Slemrod, 2004). This issue should also be seen in the light of capital mobility and the level of financial liberalisation present in the SADC region. Recent studies such as De Wet and Van Eyden (2005) and Winner (2005) have emphasised the importance and effects of capital mobility worldwide.

\section{POLICY IMPLICATIONS AND CONCLUDING REMARKS}

The SADC Tax Sub-committee was established with its primary goal: "the coordination of taxation policies to the extent necessary to improve efficiency in tax collection, safeguard regional tax bases and reduce obstacles to intra-trade and ... investment" (Department of Finance, 2000). To a certain extent the committee has succeeded in this goal, with some exceptions such as: (a) the determination of a common policy in respect of tax incentives, especially those aimed at attracting FDI into the region; and (b) the identification and promotion of areas in which coordination of direct taxation would significantly enhance the attractiveness of SADC as an investment destination. A subcommittee has also been working on the SADC Finance and Investment Protocol, and it is stated that: "Tax co-operation will increase the attractiveness of the region as an investment destination and ensure full advantage from the free trade protocol". This paper has begun addressing some of the outstanding issues, although the process is evidently on-going.

The main findings of the paper acknowledge the vulnerability of corporate tax rates in the SADC region to global influence, as the region becomes more liberalised. The

\footnotetext{
8 This result could link with other international evidence such as Rodrik (1997), that finds that there is a negative correlation between openness and government expenditures on social security and welfare.
} 
presence-of-trade variable, relating to openness and international influence, takes precedence in the determination of corporate tax rates. The openness variable is negatively related to statutory corporate rates, and positively related to the average rates. This result indicates that higher trade ratios mean lower statutory corporate rates as international influence increases. It also tends to confirm the region's dependence on trade for tax revenues, and also its ability to attract tax revenues from capital flows.

Some evidence exists in terms of an association between the government expenditureGDP ratio and the statutory and average rates, although not definitive. To a certain extent, this result could mean that lower taxes do not necessarily result in a lower supply of public goods, i.e. tax competition does not necessarily reduce public spending. Further evidence confirms the existence of the backstop scenario: across the region, there is indeed evidence of a strong association between the top individual income tax rate and the top statutory and average corporate rates. Capital gains tax and withholding taxes also seem to react to changes in the statutory rate and partly to the average corporate rate.

The paper re-emphasises the importance of international pressure in terms of future tax policy-making in the SADC region, but also opens an avenue for further efforts in terms of tax co-operation. In various respects, one could argue that South Africa acts as a so-called "Stackelberg" leader, being mostly at the forefront with the implementation of tax strategies in the SADC region. The latter strategies should also link with the relevant goals of the New Partnership for Africa's Development (NEPAD). These goals include amongst others, a full and beneficial integration of Africa into the global economy; a wider access to international trade for all; the mobilisation of resources through improved management of public revenue and expenditure; and lastly the attraction of foreign direct investment and capital flows. Naturally these goals can only be realised with peaceful settlements in war-stricken countries, the adoption of democratic dispensations and good political, economic and corporate governance throughout.

The analysis in this paper is not flawless and various restrictions, such as a lack of, have been recognised throughout. The paper should be regarded as an initial step towards future research. Although tax co-operation has been identified as the correct approach for the SADC region to ensure its attractiveness as an investment destination, further evidence and research could test the following propositions: (a) as capital mobility increases, capital taxes will decrease; (b) in the presence of two tax instruments, i.e. on mobile capital and immobile labour, labour is taxed more heavily than capital as capital mobility increases; and (c) the smaller the economy, the heavier is the tax burden on labour, and the lower is the tax burden on capital.

\section{APPENDIX A: DATA}

Statutory corporate income tax rate [CIT]: These rates are taken from several issues of PriceWaterhouseCoopers (PWC) Corporate Tax: A Worldwide Summary. This firm was previously known as Coopers \& Leibrandt and in this time period all publications regarding corporate and individual income taxes were merged into one document. Statutory CIT correspond to the marginal CIT-rate at the top bracket for central (national) government only.

Average corporate income tax rate [AVGC]: Central government corporate tax revenue divided by gross domestic product (GDP). Corporate tax revenues are taken from several issues of the IMF's Government Finance Statistics Yearbook (item 1.2). GDP is taken from the World Bank's World Development Indicator 2000 CD-ROM.

Statutory personal income tax rate [PIT]: These rates are taken from several issues of PWCs Individual 
Tax: A Worldwide Summary. These rates correspond to the marginal individual income tax rate at the top bracket for the central government only.

Statutory personal income tax rate [PIT] interact with an indicator for the presence of capital gains tax [PITNOCAP]: (=1 if there is no capital gains tax, adopting PIT value for that specific year, and 0 otherwise). These are taken from PWCs Individual Tax: A Worldwide Summary.

An indicator on available/missing information [INDCMISS]: (=1 if NOCAP is not missing, and 0 otherwise).

\section{(a) Internal and/or regional variables}

Central government expenditure as ratio of GDP [GOVEXP]: Government expenditures are taken from several issues of the IMF's Government Finance Statistics Yearbook (item II). GDP is taken from the World Bank's World Development Indicator 2000 CD-ROM.

Withbolding Tax [W]: This is a tax on earnings (royalties, management fees), interest or dividend payments deducted at source. The tax is designed to simplify the collection of tax and to ensure that tax is not evaded. By taxing dividends due for repatriation, it is hoped that foreign-owned companies will be encouraged to invest in the country where its subsidiary is located.

Source/Residence principle [SR]: A dummy variable was included to describe the method of international taxation, either a source or residence principle.

Oil or mineral production [Oil/MINERAL]: World Petroleum price multiplied by production of crude oil, NGPL, other liquids, and refinery, divided by population (dollars*thousands of barrels per day/millions of people). See World Bank's World Development Indicator 2000 CD-ROM. If information on oil was not available, mineral prices (US\$) were multiplied by the relevant production figures. However, one has to remember that the sample of countries included in this paper use different tax rates depending on the specific mineral involved and in some cases a tax formula, such as gold production in South Africa, is utilised.

Natural log of per-capita electricity usage (in kW/year) [ In_ELEC]: These are taken from the World Bank's World Development Indicator 2000 CD-ROM.

(b) External and/ or international variables

Natural log of population (millions) [ln_POP]: See World Bank's World Development Indicator 2000 CD-ROM.

Exports and Imports [O]: [Exports (X)/Gross Domestic Product (GDP) + Imports (Z)/Gross Domestic Expenditure (GDE)]/2. See World Bank's World Development Indicator 2000 CDROM.

\section{APPENDIX B: CAPITAL INCOME TAX IN THE SADC REGION}

Table B.1. Capital income tax systems in selected federations and SADC, 2003

\begin{tabular}{|c|c|c|c|c|c|c|}
\hline \multirow{3}{*}{ COUNTRY } & \multirow{3}{*}{$\begin{array}{l}\text { INVESTMENT } \\
\text { INCENTIVES }(\text { EPZ) }\end{array}$} & \multirow{3}{*}{$\begin{array}{l}\text { CIT-RATE + } \\
C G T \text { ON } \\
\text { RESIDENTS (\%) }\end{array}$} & \multicolumn{4}{|c|}{$\begin{array}{l}\text { TAXES ON PASSIVE INCOME (DIVIDENDS, } \\
\text { INTEREST, ROYALTIES \& FEES) }\end{array}$} \\
\hline & & & \multirow{2}{*}{$\begin{array}{l}\text { CIT-RATE + CGT \& } \\
\text { PIT ON NON- } \\
\text { RESIDENTS }(\%)\end{array}$} & \multicolumn{2}{|c|}{ Domestic investors } & \multirow{2}{*}{$\begin{array}{l}\text { International } \\
\text { investors } \\
\text { Passive } \\
\text { income }^{3}(\%)\end{array}$} \\
\hline & & & & $\begin{array}{l}\text { PIT-rates + } \\
C G T(\%)\end{array}$ & $\begin{array}{l}\text { Passive } \\
\text { income }(\%)\end{array}$ & \\
\hline Argentina $^{1}$ & $\begin{array}{l}2 \text { FTZs (tax \& duty } \\
\text { free) }\end{array}$ & 35 & 35 & $\begin{array}{l}0-47 / 24.5^{*} \text { on } \\
\text { foreigners }\end{array}$ & $\begin{array}{l}0 \text { dividends; } 6-35^{*} \\
\text { on interest \& } \\
\text { royalties }\end{array}$ & $10-35 *$ \\
\hline Brazil $^{1}$ & $1 \mathrm{EPZ}(\operatorname{tax} \&$ duty free) & $\begin{array}{l}15 \& \text { surcharge } \\
\text { of } 10\end{array}$ & 15 & $0-25$ & $\begin{array}{l}0 \text { dividends after } \\
1995\end{array}$ & $0-25^{*}$ \\
\hline India $^{1}$ & $\begin{array}{l}7 \text { EPZs ( } 5-10 \text { year tax } \\
\text { holiday, duty free } \\
\text { imports) }\end{array}$ & $\begin{array}{l}35+20 \text { on long term } \\
\text { gains }\end{array}$ & $\begin{array}{l}35+20 \text { on long term } \\
\text { gains }\end{array}$ & $0-40$ & $\begin{array}{l}0 \text { dividends; } 5-20 * \\
\text { on interest \& } \\
\text { royalties }\end{array}$ & $10-48 *$ \\
\hline Angola & $\begin{array}{l}\text { Exemption of } 3 \text { to } 5 \\
\text { years for new industries }\end{array}$ & $\begin{array}{l}35 \text { (oil industry } \\
\text { special tax rates) }\end{array}$ & $\begin{array}{l}35 \text { (oil industry } \\
\text { special tax rates) }\end{array}$ & $0-15$ & $15^{*}$ on dividends & $15^{*}$ dividends \\
\hline
\end{tabular}




\begin{tabular}{|c|c|c|c|c|c|c|}
\hline Botswana & $\begin{array}{l}\text { IFSC (flat CIT-rate of } \\
15 \% \text { for } 20 \text { years; } \\
\text { exemption for } \\
\text { withholding taxes) }\end{array}$ & $15+25$ & $15+\underline{25}$ & $0-25+50$ of gain & $\begin{array}{l}15^{*} \text { on dividends; } \\
\text { CIT/PIT on rest }\end{array}$ & $15^{*}$ \\
\hline DRC & $\begin{array}{l}\text { Investment \& export } \\
\text { incentives }\end{array}$ & $\begin{array}{l}45 ; 7.84 \text { for oil } \\
\text { subcontractors }+ \\
O I^{* *}\end{array}$ & $\begin{array}{l}45 ; 7.84 \text { for oil } \\
\text { subcontractors }+O \\
\& 20\end{array}$ & $\begin{array}{l}5-65(8 \text { on } \\
\text { I supplementary } \\
\text { income) }\end{array}$ & $\begin{array}{l}20^{*} \text { on dividends, } \\
\text { interest; CIT/PIT } \\
\text { on royalties; } 22^{*} \\
\text { on directors' fees }\end{array}$ & $20 * \& 22$ fees \\
\hline Lesotho & $\begin{array}{l}\text { Investment and export } \\
\text { incentives }\end{array}$ & $\begin{array}{l}15 \text { on } \\
\text { manufacturing; } 35 \\
\text { on other; or advance } \\
\text { CIT of } 53.8+O I\end{array}$ & $\begin{array}{l}35+25 \text { of gain \& } 25 \\
\text { e } 35\end{array}$ & $25-35+O I$ & $\begin{array}{l}0 \text { dividends (from } \\
\text { Lesotho co.) but } \\
\text { CIT/PIT (from } \\
\text { foreign co.); } \\
\text { CIT/PIT on rest }\end{array}$ & $\begin{array}{l}25^{*} \text { dividends, } \\
\text { interest, fees; } 15 \text { - } \\
25 \text { on rest }\end{array}$ \\
\hline Malawi & $\begin{array}{l}\text { EPZs (CIT-rate of } 0 \% \\
\text { for } 10 \text { years }\end{array}$ & $\begin{array}{l}38 ; 24 \text { on life-assure } \\
+O I\end{array}$ & $\begin{array}{l}38+\text { OI \& } 15 \text { on } \\
\text { gross income }\end{array}$ & $0-38+O I$ & $\begin{array}{l}0 \text { dividends; } \\
\text { CIT/PIT on rest } \\
\text { with } 20^{*}\end{array}$ & $\begin{array}{l}0 \text { dividends; } 15^{*} \\
\text { on rest }\end{array}$ \\
\hline Mauritius & $\begin{array}{l}\text { EPZs (10-20 year tax } \\
\text { holiday, no customs } \\
\text { duties) }\end{array}$ & $\begin{array}{l}35 ; 15 \text { on } \\
\text { manufacturing } \\
\text { textiles } \\
32(10 \text { for }\end{array}$ & $15-25$ & $5-25$ & $\begin{array}{l}0 \text { dividends \& } \\
\text { interest; CIT on } \\
\text { royalties \& fees }\end{array}$ & 0 \\
\hline Mozambique & $\begin{array}{l}\text { IFZs (tax holiday of } 0-6 \\
\text { years) }\end{array}$ & $\begin{array}{l}6 \text { agriculture) \& } \\
\text { municipal surtax }+ \\
18 \text { dividends }\end{array}$ & $32 \& 15^{*}$ & $8-40+18^{*}$ & $\begin{array}{l}18^{*} \text { on dividends } \\
\& \text { interest }\end{array}$ & $8-25^{*}$ \\
\hline Namibia & $\begin{array}{l}3 \text { EPZs (unlimited tax } \\
\text { holiday) }\end{array}$ & 35 & $35 \& 0-36$ & $0-36$ & $\begin{array}{l}0 \text { dividends, } \\
\text { CIT/PIT on rest }\end{array}$ & $\begin{array}{l}10 * \text { dividends; } 0- \\
36 \text { interest \& fees; } \\
10.5 \text { royalties }\end{array}$ \\
\hline Seychelles & $\begin{array}{l}\text { ITZ license (exempt } \\
\text { from all taxes) }\end{array}$ & $0-40$ & $0-40$ & None & $\begin{array}{l}0 \text { dividends; } 0 \\
\text { interest (non- } \\
\text { financial inst.); } \\
\text { CIT/PIT on rest }\end{array}$ & $0-15^{*}$ \\
\hline South Africa & $\begin{array}{l}\text { IDZs (duty free } \\
\text { imports) and } \\
\text { employment incentives; } \\
\text { the tax holiday expired } \\
\text { in } 1999 \text {. }\end{array}$ & $\begin{array}{l}30 \text { \& } 12.5 \text { (STC) on } \\
\text { dividends ( } 35 \\
\text { employment co, } 15- \\
30 \text { small business); } \\
\text { formula for gold } \\
\text { production }\end{array}$ & $30+15 \& 0-40^{4}$ & $0-40+10.5^{4}$ & $\begin{array}{l}\text { PIT dividends; } \\
\text { CIT/PIT on rest }\end{array}$ & $\begin{array}{l}0 \text { dividends, } 0 \\
\text { interest (except } \\
\text { CMA), } 0 \text { royalties, } \\
\text { know-how } 5-12\end{array}$ \\
\hline Swaziland & $\begin{array}{l}\text { Investment \& export } \\
\text { incentives for targeted } \\
\text { sectors (special } 15 \% \text { ) }\end{array}$ & 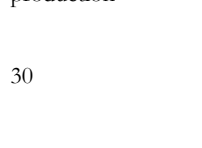 & $30 \& 33$ & $12-33$ & $\begin{array}{l}0 \text { dividends of co., } \\
10 / 20 \text { of } \\
\text { individuals; } 10 \text { on } \\
\text { interest; } 0 \\
\text { royalties; } 33 \text { fees }\end{array}$ & $\begin{array}{l}12.5 / 15 \text { dividends; } \\
10 \text { interest; } 15 \text { on } \\
\text { royalties, fees }\end{array}$ \\
\hline Tanzania & $\begin{array}{l}\text { Investment incentives } \\
\text { for oil \& other mining }\end{array}$ & $30+O I$ & $30+O I \& 0-30$ & $0-30+O I$ & $\begin{array}{l}10^{*} \text { dividends; } 15^{*} \\
\text { interest; } 20 \\
\text { royalties; CIT/PIT } \\
\text { on fees }\end{array}$ & $\begin{array}{l}20 * \text { dividends, } \\
\text { royalties, fees; } 15 * \\
\text { interest }\end{array}$ \\
\hline Zambia & $\begin{array}{l}\text { Tax incentives for } \\
\text { farming \& non- } \\
\text { traditional sectors }\end{array}$ & $\begin{array}{l}\text { 35; } 30 \text { (listed on } \\
\text { ZSE); 35-45 (banks) }\end{array}$ & $\begin{array}{l}\text { 35; } 30 \text { (listed on } \\
\text { ZSE); 35-45 (banks) }\end{array}$ & $10-30$ & $15^{*}$ & $15^{*}$ \\
\hline Zimbabwe & $\begin{array}{l}7 \text { EPZs (5-year tax } \\
\text { holiday, duty-free } \\
\text { imports and exports; } \\
\text { special CIT-rate of } \\
10 \% \text { ) }\end{array}$ & $30+10 / 20$ & $30+10 / 20$ & $\begin{array}{l}0-40(\& 25 \\
\text { surcharge })+ \\
10 / 20\end{array}$ & $\begin{array}{l}0 \text { dividends of co., } \\
15 / 20^{*} \text { of } \\
\text { individuals; } \\
20 / 30^{*} \text { interest, } \\
\text { CIT/PIT on rest }\end{array}$ & $\begin{array}{l}20^{*} \text { dividends; } 10^{*} \\
\text { interest; } 5 / 20^{*} \\
\text { royalties, fees }\end{array}$ \\
\hline
\end{tabular}

Notes: $*$ Withheld; $* *$ OI $=$ Ordinary income

(1) The three federations, namely Argentina, Brazil and India apply sub-national corporate taxes, and the CIT- and PIT-rates therefore only represents rates at federal level, and the capital income tax systems can therefore also differ from one sub-national authority to the next.

(2) These investment ( $\operatorname{tax})$ incentives include a wide variety of incentives mostly in export sectors.

(3) The tax rate applicable on passive income (dividends, interest, royalties and fees) is subject to the double taxation agreements that have been reached between the federations and other countries, and the SADC members and other countries or other SADC members.

(4) A capital gains tax (CGT) has been applicable in South Africa from 1 October 2001. Individuals are taxed at $25 \%$ of the gain against PIT, i.e. effectively $0-10.5 \%$. Corporations are taxed at $50 \%$ of the gains against CIT, i.e. effectively $15 \%$ with special inclusion rates for small and employment businesses; business or family trusts; retirement funds; unit trusts and life assurors.

Source: Compiled from the International Bureau for Fiscal Documentation (http://online.ibfd.org), 2004; Ernest and Young, 2003; and PWC, 2003/04 


\section{REFERENCES}

AMUSA, H.A. (2004). Macroeconomic approach to estimating effective tax rates in SA. South African Journal of Economic and Management Sciences, Vol. 7, No. 1, pp. 117-131.

BACHETTA, P. AND ESPINOSA, M. (1992). Information sharing and tax competition among governments. Journal of International Economics, pp. 103-121.

BLACK, P.A.; CALITZ, E. AND STEENEKAMP, T.J. (1999). Public Economics for South African Students. Cape Town: Oxford University Press.

BIRD, R.M. 1(1992). Tax Reform in Latin America: A Review of Some Recent Experiences. Latin American Review, Vol. 27, pp. 7-36.

BURGESS, R. AND STERN, N. (1992). Taxation and Development. London: London School of Economics.

BUCOVETSKY, S. AND WILSON, J.D. (1991). Tax competition and two tax instruments. Regional Science and Urban Economics, Vol. 21, pp. 333-350.

DE WET, A.H. AND VAN EYDEN, R. (2005). Capital Mobility in Sub-Saharan Africa: A Panel Data Approach. South African Journal of Economics, Vol. 73, No. 1, pp. 22-35.

DEPARTMENT OF FINANCE. (2000). The Budget Review. Pretoria: Government Printer.

DIAMOND, P.A. AND MIRRLESS, J. (1971). Optimal Taxation and Public Production. American Economic Review, Vol. 61, pp. 8-27 \& pp. 261-278.

DIXIT, A. AND NORMAN, V. (1980). The theory of international trade. London: Cambridge University Press.

EUROPEAN COMMUNITIES-COMMISSION (EC). (1997). Conclusions of the ECOFIN Council Meeting on 1 December 1997 concerning taxation policy (including Code of Conduct for business taxation). Official Journal of the European Communities, 98/C2/01.

ERNEST \& YOUNG. (2004). African website. (www.ernest\&young.co.za).

FRENKEL, J.A.; RAZIN, A. \& SADKA, E. (1991). International taxation in an integrated world. Cambridge, MA: MIT Press.

GARETT, G. (1995). Capital mobility, trade, and the domestic politic of economic policy, International Organization, Vol. 49, pp. 657-687.

GINSBERG, A.S. (1991). Tax Havens. New York: New York Institute of Finance.

GORDON, R.H. (1986). Taxation of Investment and Savings in the World Economy. American Economic Review, Vol. 76, pp. 1086-1102.

(1992). Can capital income taxes survive in open economies? Journal of Finance, Vol. 47, pp. 1159-1180.

GRAVELLE, J. (1994). Economic Effects of Taxing Capital Income. Cambridge: MIT Press.

HAUfLER, A. (2001). Taxation in a Global Economy. Cambridge: Cambridge University Press.

INTERNATIONAL MONETARY FUND (IMF). (2001). International Financial Statistics. Washington D.C.: IMF.

JANEBA, E. (1994). International Tax Competition. Inaugural-Dissertation. Bonn: Rheinischen Friedrich-WilhelmsUniversitat.

JANEBA, E. (1995). Corporate income tax competition, double taxation treatise, and foreign direct investment. Journal of Public Economics, Vol. 56, pp. 311-325.

JORGENSON, D.W. (1963). Capital Theory and Investment Behaviour. American Economic Review, Vol. 53, No. 2, pp. 247259.

KING, M.A. AND FULLERTON, D. (eds.) (1984). The Taxation of Income and Capital: A Comparative Study of United States, United Kingdom, Sweden and West Germany. NBER, University of Chicago Press: Chicago, Illinois.

MUSGRAVE, P.B. (1990). Merits and Demerits of Fiscal Competition. (In Prudhomme, R. (ed.), Public Finance with Several Levels of Government, Brussels: Proceedings of the $46^{\text {th }}$ Congress of the IIPF).

NATIONAL TREASURY OF SOUTH AFRICA (NTSA). (2001). The Budget Review. Pretoria: NTSA.

NEWBERRY, B AND STERN, N. (1987). Economic development. London School of Economics (LSE), Discussion Paper.

ORGANISATION FOR ECONOMICS COOPERATION AND DEVELOPMENT (OECD). (1977). Model Tax Convention on Income and on Capital. Report of OECD Committee on Fiscal Affairs. Paris: OECD.

(OECD). (1991). Taxing Profits in a Global Economy: Domestic and International issues. Paris: OECD Publications.

(OECD). 1998. Harmful Tax Competition: An Emerging Global Issue. Paris: OECD Publications.

PRICEWATERHOUSECOOPERS (PWC). (1980-2004). Corporate Taxes: Worldwide Summaries. New York: John Wiley \& Sons Inc.

(PWC). (1980-2004). Individual Taxes: Worldwide Summaries. New York: John Wiley Sons Inc.

QUINN, D. (1997). The correlates of change in international financial regulation, American Political Science Review, Vol. 91, pp. 531-551.

RAZIN, A. AND SADKA, E. (1993). The Economy of Modern Israel: Malaise and Promise, The University of Chicago Press: Chicago, IL.

RICARDO, D. (1817). On the Principles of Political Economy and Taxation. (In Scraffa, P.(ed.), The Works and Correspondence of David Ricardo, vol.1, Cambridge: Cambridge University Press).

ROBINSON, Z. (2002). Tax Competition and its implications for Southern Africa. PhD thesis (unpublished), University of Cape Town.

RODRIK, D. (1997). Has globalisation gone too far? Washington DC: Institute for International Economics.

ROSEN, H.S. (2003). Public Finance. $7^{\text {th }}$ Edition. New York: McGraw-Hill.

SOUTHERN AFRICAN DEVELOPMENT COMMUNITY (SADC). (2001). SADC Member inputs. Telephonic and electronic interviews. Pretoria. 
SLEMROD, J. (2004). Are corporate tax rates, or countries, converging?, Journal of Public Economics, Vol. 88, pp. $1169-1186$. SMITH, A. (1776). An Inquiry into the Nature and Causes of Wealth of Nations. London: JM Dent and Sons.

STEENEKAMP, T.J. (1996). Some aspects of corporate taxation in South Africa: the Katz Commission. South African Journal of Economics, Vol. 64, No. 1, pp. 1-19.

TANZI, V. (1995). Taxation in an integrating world. Washington D.C.: The Brookings Institution. (1996). Globalization, Tax Competition and the Future of Tax Systems. Washington D.C.: IMF Working Paper.

(1999). Is There a Need for a World Tax Organization? (In Razin, A. \& Sadka, E. (eds.), The Economics of Globalization: Policy Perspectives from Public Economics, New York: Cambridge University Press, pp. 173-186).

THE ECONOMIST. (2000). A Survey of Globalisation and Tax. January 29, pp. 1-18.

UNITED NATIONS CONFERENCE ON TRADE AND DEVELOPMENT (UNCTAD). (1998). World Investment Report 1998: Trends and Determinants. New York and Geneva: United Nations.

WINNER, H. (2005). Has Tax Competition Emerged in OECD Countries? Evidence from Panel Data. International Tax and Public Finance, Vol. 12, No. 5, pp. 667-687.

WORLD BANK. (1991). Lessons of Tax Reform. Washington D.C.: World Bank Publications. (1980-2000). World Development Indicators CD-ROM.

(2000). Entering the $21^{\text {st }}$ Century. World Development Report 1999/2000. New York: Oxford University Press. (2001). Poverty Reduction. World Development Report 2000/2001. New York: Oxford University Press.

ZELNER, A. (1962). An Efficient Method of Estimating Seemingly Unrelated Relations and Tests for Aggregation Bias, J.A.S.A, Vol. 57, pp. 348-67.

ZODROW, G.R. AND MIESZKOWSKI, P. (1986). Pigou, Tiebout, Taxation, and the Under-provision of Local Public Goods. Journal of Urban Economics, Vol. 19, pp. 12-32. 